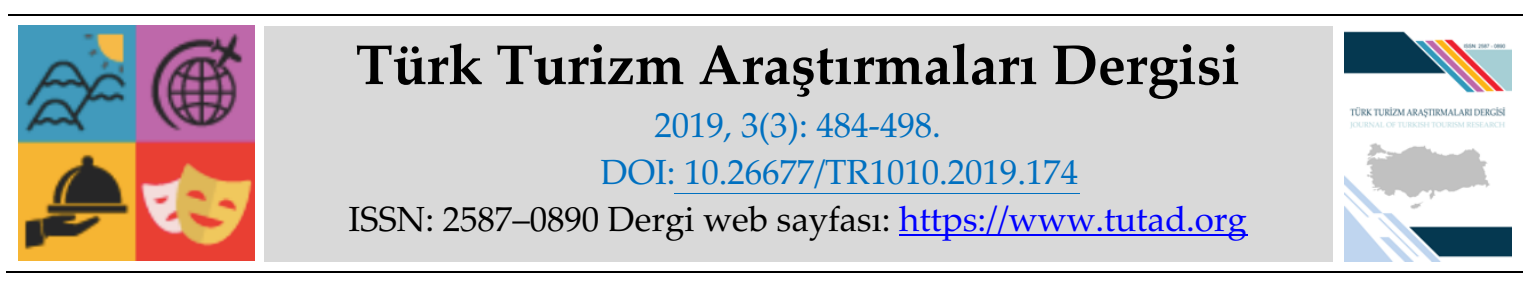

ARAȘTIRMA MAKALESI

\title{
Turistlerin Yöresel Yiyecek Beğenilerinin Davranışsal Niyetlere Etkisi: Cunda Adası Örneği ${ }^{1}$
}

\author{
Bilim Uzmanı Fatih ÇOLAKOĞLU, Balıkesir Üniversitesi, Burhaniye Uygulamalı Bilimler \\ Yüksekokulu, Turizm İşletmeciliği ve Otelcilik Bölümü, Balıkesir, e-posta: \\ fatih.colakoglu@outlook.com.tr \\ ORCID: https://orcid.org/0000-0001-6150-7436
}

Prof. Dr. M. Oğuzhan İLBAN, Balıkesir Üniversitesi, Burhaniye Uygulamalı Bilimler Yüksekokulu, Gastronomi ve Mutfak Sanatları Bölümü, Balıkesir, e-posta: ilban@balikesir.edu.tr

ORCID: https://orcid.org/0000-0002-2147-8252

Öz

Bu çalışmada; Cunda Adası'nı ziyaret eden yerli turistlerin, Cunda Adası'na özgü yöresel yiyeceklerin sunulduğu restoranlardaki yöresel yiyecek beğenilerinin, memnuniyete ve memnuniyetin, satın alım sonrası davranışlara olan etkilerinin tespit edilmesi amaçlanmaktadır. Bu etkilerin ortaya çıkartılabilmesi adına Cunda Adası restoranlarında bir ön test gerçekleştirilmiş ve yöresel yiyecekler ölçeği oluşturulmuştur. Yöresel yiyecekler, müşteri memnuniyeti ve davranışsal niyetler ile katılımcıların tanımlayıcı özelliklerinin bulunduğu anket 406 yerli turist üzerinde gerçekleştirilmiş ve beklenen etkiler yapısal eşitlik modeli vasıtasıyla analize tabi tutulmuştur. Yapılan analizler sonucunda katılımcıların yöresel yiyecek ölçeğinin alt boyutlarından olan yöresel otlar ve deniz ürünlerini beğenilerinin müşteri memnuniyeti üzerinde, müşteri memnuniyetinin ise davranışsal niyetler üzerinde etkili olduğu tespit edilmiştir.

Anahtar Kelimeler: Yöresel Yiyecekler, Müşteri Memnuniyeti, Davranışsal Niyetler, Cunda Adas1.

Makale Gönderme Tarihi: 06.05.2019

Makale Kabul Tarihi: 01.07.2019

\section{Önerilen Atıf:}

Çolakoğlu, F. ve İlban, M. O. (2019). Turistlerin Yöresel Yiyecek Beğenilerinin Davranışsal Niyetlere Etkisi: Cunda Adası Örneği, Türk Turizm Araştırmaları Dergisi, 3(3): 484-498.

(C) 2019 Türk Turizm Araştırmaları Dergisi.

${ }^{1} \mathrm{Bu}$ çalışma Balıkesir Üniversitesi Sosyal Bilimler Enstitüsü Uluslararası Ticaret ve Pazarlama Anabilim dalında hazırlamış olduğumuz Tez çalışmamızdan hareketle hazırlanmıştır. 


\title{
Journal of Turkish Tourism Research
}

2019, 3(3): 484-498.

DOI: $10.26677 /$ TR1010.2019.174

ISSN: 2587-0890 Journal Homepage: https://www.tutad.org

RESEARCH PAPER

\section{The Effect of Local Food Tastes of Tourists to Behavioral Intentions: The Case of Cunda Island}

Fatih ÇOLAKOĞLU, (MSc.) Balıkesir University, Burhaniye School of Applied Sciences, Department of Tourism and Hotel Management, Balıkesir, e-mail: fatih.colakoglu@outlook.com.tr ORCID: https://orcid.org/0000-0001-6150-7436

Prof. Dr. M. Oğuzhan İLBAN, Balıkesir University, Burhaniye School of Applied Sciences, Department of Gastronomy and Culinary Arts, Balıkesir, e-mail: ilban@balikesir.edu.tr ORCID: https://orcid.org/0000-0002-2147-8252

\begin{abstract}
The aim of this study is to determine the effects of local food tastes, satisfaction and satisfaction on the post-purchase behaviors of the local tourists visiting Cunda Island. Cunda Island restaurants were pre-tested and a local food scale was created. A survey on local food, customer satisfaction and behavioral intentions and descriptive characteristics of participants was conducted on 406 domestic tourists and expected effects were analyzed by structural equation model. As a result of analyzes, it has been determined that the taste of local plants and seafood, which are the sub-dimensions of the regional food scale, have an effect on customer satisfaction in customer satisfaction and behavioral intentions.
\end{abstract}

Keywords: Local foods, Customer Satisfaction, Behavioural Intentions, Cunda Island. Received: 06.05.2019

Accepted: 01.07.2019

\section{Suggested Citation:}

Çolakoğlu, F. and İlban, M. O. (2019). The Effect of Local Food Tastes of Tourists to Behavioral Intentions: The Case of Cunda Island, Journal of Turkish Tourism Research, 3(3): 484-498.

(C) 2019 Türk Turizm Araştırmaları Dergisi. 


\section{Gíriş}

Dünya'da turizm sektörü hızla gelişmektedir ve turizm sektörünün alt bileşenleri sektörün büyüme oranını artırmakta, mal ve hizmetlerini farklılaştırarak, yeni müşteri tipolojilerine daha kaliteli şekilde hizmet sunmaktadır. Dolayısıyla sektörün alt bileşenlerinden olan ve günümüzde büyük ilgi odağı haline gelen gastronomi turizmi ve gastronomi turizmi içerisinde sunulan yöresel ürünler, turistlerin yeni destinasyonları keşfetmeleri ve o destinasyonlarda sunulan yöresel lezzetleri araştırmalarında en önemli motivasyon kaynakları olarak gösterilmektedir (Dalgıç, Güler ve Birdir, 2016). Yedikleri ve içtikleri ile daha ilgili olmaya başlayan turistlerin memnuniyeti açısından, bu hizmetleri sunan restoranlar ise ürünlerinin hazırlanması, lezzetlerinin artırılması, mekânların ambiyansının iyileştirilmesi ile misafirlerinde olumlu bir etki yaratarak, sadık müşteriler yaratmaya çalışmaktadır (Lin ve Mattila, 2006). Bu çalışmada da rekabetin yoğun olarak yaşandığı turizm sektöründe faaliyet gösteren restoranların sunduğu yöresel yiyecekler, bu yiyeceklerden dolayı edinilmiş memnuniyet ile memnuniyetin Cunda Adası'nı tekrar ziyaret etme ve eş, dost ya da akrabalarına tavsiye etme niyeti araştırılmıştır.

Günümüzde dünya turizmindeki harcamalar incelendiğinde, tatile çıan turistlerin temel harcamalarının \%28'sini yeme içme gereksinimlerine harcadıkları gözükmektedir. Ancak Gastronomi turizmi içerisinde seyahatlerini gerçekleştiren turistlerin temel yeme - içme harcamaları \%35 olarak karşımıza çıkmaktadır (Gastronomi Turizmi Derneği, 2018). Bu durumla ilişkili olarak Türkiye turizminin yeme içme gelirleri 2002 - 2017 yılları arasında incelendiğinde; yeme içme gelirlerinin, turizm gelirleri içerisindeki payı \%20'dir (TÜİK, 2018). Türkiye bu gelirler ile turizm sektöründe en yakın rakibi olan Yunanistan'ın dahi gerisinde kalmaktadır. Gastronomi turizmi gelirlerinin artırılması noktasında önemli rol üstlendiği varsayılmaktadır. Bununla birlikte, yöresel yiyecekler ile ilgili izlenimler tüketici hakkında o destinasyona ait fikirler oluşmasına sebep olmaktadır. Diğer bir söyleyişle yöresel yiyecekleri tecrübe eden turistlerin memnun olarak restoranlardan ayrılması, turistlerin o restoranları ve dolayısıyla o destinasyonları tekrar ziyaret etmesine ve tavsiye etmesine etki edecektir. Buradan hareketle, yöresel yiyeceklere yönelik tüketici memnuniyetinin destinasyonu tekrar ziyaret ve tavsiye etme üzerindeki etkisinin belirlenmesi araştırmanın temel problemini, ilgili literatürde ulaşılan ve memnuniyetle tekrar ziyaret arasındaki etkileşimi ortaya koyan sonuçlara ilaveten bu memnuniyetinin yöresel yiyecek kanalıyla oluşturulduğunun ortaya koyulması da çalışmanın amacını oluşturmaktadır.

Literatür incelendiğinde müşteri memnuniyetinin davranışsal niyetleri etkilediğine dair (Kozak ve Rimmington, 2000; Bigne vd., 2001; Kozak 2001; Petrick vd., 2001; Yüksel, 2001; Feng ve Jang, 2004; Yoon ve Uysal, 2005; Duman ve Özturk, 2005; Zabkar vd., 2010; Heung ve Gu, 2012; Shi vd., 2014; İlban vd., 2015) birçok araştırma yer almasına karşın, bu etkinin yöresel yiyecek beğenileri kanalıyla oluşturulduğunu gösteren çalışmalara pek fazla rastlanılmamaktadır. Buradan hareketle çalışmanın evrenini oluşturan; Cunda Adasını ziyaret eden yerli turistlerin yöresel yiyecek beğenileri ve yöresel yiyecek beğenilerinin etki etiğini varsaydı̆̆ımız müşteri memnuniyeti ve davranışsal niyetler kavramları araştırılması gereken bir konu olarak değerlendirilmektedir.

\section{LITTERATÜR TARAMASI}

\section{Yöresel Yiyecekler}

İnsan yaşamında yeme - içme mecburiyeti, mutfak alanında belli kurallar geliştirilmesine ve bu kurallar da mutfak kültürünün gelişmesine neden olmuştur. Mutfak kültürü, insanların doyma 
gereksinimlerini karşılayan yiyecek içecek çeşitlerinin hazırlanması, pişirilmesi, tüketilmesi ve saklanması işlemlerini kapsayan bir süreçtir. Bununla birlikte, yiyecek ve içecekler için yapılan faaliyetlerinin uygulandığı yer, geçmişten gelen yeme - içme alışkanlıkları, donanım, inanç ve uygulamalar kendine has kültürel bir yapıyı da anlatmaktadır. Kültürün en önemli parçalarından biri de kuşkusuz yöreye ait yemeklerdir (Lopez ve Sanchez, 2012). Turistlerin tatile gitmek için tercih ettikleri destinasyonların bölgesel kültürleri, karar verme noktasında önemli etkenlerin başında gelmektedir. Bölge kültürünün önemli bir bölümünü de yörenin yemek kültürü oluşturmaktadır (Yetiş 2015). Bu durumla ilişkili olarak turistler, yöresel tatlarla bir araya getirilmiş yemekleri tüketmek istekliliğindedir (Warde, 1997).

Yöresel yiyecekler, insanların uzun yıllar bir bölgede birlikte yaşamaları sonucunda, daha çok özel günlerde tüketilen, yöre halkının diğer yiyeceklerden üstün tuttuğu ve genel olarak bir olay sonucu kültürlerde yer edinmiş yiyeceklerdir (Hatipoğlu vd., 2013). Yöresel yiyecekler, turistleri bölge kültürüne yakınlaştıran, o bölgeyi hissetmelerini sağlayan, ait olduğu yörenin sembolik özelliklerini yansıtan ve destinasyonun çekiciliğini artıran ürünler olarak ifade edilmektedir (Au ve Law, 2002). İçerisinde bulunduğumuz zamanda, bir bölge için oluşabilecek çekicilik unsurlarının arasında bölgenin mutfak kültürü, gün geçtikçe önemini artırmaktadır (Doğdubay vd., 2011). Bir bölge ya da yöre adına farkındalık oluşturabilecek unsurların arasında bölge veya yöreye özgü yemekler ilgi çekici unsurlar olarak gösterilmektedir. Bölge ya da yöreye gelen ziyaretçiler, yöresel olarak hazırlanan yiyecek ve içeceklerin deneyimlenmesine öncelik göstermektedirler. Yöresel ürünler ile elde edilen yemekler ve yörede yetiştirilen gıda ürünlerinin tüketimine turistlerin hassasiyet gösterdikleri bilinmektedir (Deveci vd., 2013). Dolayısıyla, yöresel yiyecekler, bölgede turizm sektöründe hizmet veren işletmeler açısından bir kaynak olarak değerlendirilmektedir (Kim vd., 2012).

\section{Müşteri Memnuniyeti}

Müşteri memnuniyetinin en temel iki öğesinden biri olan müşteri kavramı literatürde çeşitli çalışmalarca tanımlanmaya çalışılmıştır (Zeithalm vd., 1996; Oliver, 1981; Parasuraman vd., 1991; Baytekin, 2005). Parasuraman, Zeithalm ve Berry (1991) çalışmalarında müşteriyi; bilânçoda gösterilmese de bir işletmenin sahip olduğu en değerli varlıklardır şeklinde tanımlamışlardır. Başka bir ifadeyle, işletmenin bir bölümünün çıktılarını kullananlar veya bu çıtıların etkilediği insanlar, organizasyonlar, sistemler veya süreçler de birer müşteridir. Müşteri memnuniyetinin diğer bir öğesi olan memnuniyet kavramı, yaygın olarak "tüketicilerin beklentileri ile tüketim sonrası ortaya çıkan algılarının kıyaslanması sonucunda ortaya çıkan psikolojik durum" olarak tanımlanmaktadır (Oliver, 1981). Memnuniyet üzerine literatürde birçok araştırma bulunmaktadır. Bu çalışmalardan birinde memnuniyet tanımı "algılanan performans ya da kalite ile beklentiler arasındaki fark" olarak açıklanmaktadır (Baytekin, 2005).

Müşteri ve memnuniyet temel kavramalarından oluşan müşteri memnuniyetini Zeithmal ve Bitner (2000) çalışmalarında, 'bir ürünün müşteri gereksinim ve beklentilerini karşılayıp karşılamaması açısından değerlendirilmesi' olarak tanımlamaktadır. Müşteri, tüm işletmelerde üretilecek ürün ya da uygulamaya sokulacak kararların alınmasından önce düşünülmesi gereken en önemli etkendir. Dolayısıyla tüm sektörlerde müşteri memnuniyeti büyük önem arz etmektedir. Aynı zamanda hizmet endüstrisinde bulunan işletmeler açısından müşteri memnuniyeti önemli bir verimlilik göstergesi olarak kabul edilmektedir. Araştırmanın temel alanını oluşturan yiyecek işletmelerinde de müşterilerin memnuniyet seviyesini, o an içerisinde bulunduğu restoranın ambiyansından, ona sunulan üründeki damak lezzetine kadar birçok değişken etkileyebilmekte ve dolayısıyla işletmeler ürünün hazırlanma aşamasından sunumuna, fiyatından, hijyen ve sanitasyon uygulamalarına kadar tüm süreci iyi analiz ederek 
müşterilerinin gereksinim ve beklentileri doğrultusunda memnuniyet yaratarak rekabet avantajı elde etmeye çalışmaktadır.

\section{Davranışsal Niyetler}

Davranışsal niyetler, bir tüketicinin, deneyimlediği üründen sonra, o ürünü bir sonraki deneyimi için isteyip istemediğini gösteren bütünsel davranışlardır (Yang vd., 2011). Başka bir deyişle davranışsal niyet, kişinin bir sonraki davranışta gerçekleştirmeyi ya da gerçekleştirmemeyi planladığı davranış derecesi olarak tanımlanabilmektedir. Davranışsal niyet öngörülemeyen olaylarda ya da zamanda değişebilmesine rağmen, gerçek davranışın ön göstergesi olarak kabul edilmektedir. Deneyimlenen bir mal ya da hizmetin sonucunda memnuniyet veya memnuniyetsizlik meydana gelmektedir. Memnuniyetin bir çıktısı olan davranışsal niyetlerde; ağızdan ağıza iletişim ve şikâyet gibi davranışlar gösteren müşterilerin etkilendiği davranışlar bütünü olarak ifade edilebilmektedir (Lyon ve Powers, 2004).

Davranışsal niyetler, herhangi bir tüketicinin tecrübe ettiği ürüne ya da ürünü üreten kuruluşlara dair geri bildirimlerini ifade eden davranışları kapsamaktadır. Bu noktadan hareketle; tüketicilerin deneyimlerinden edindiği tatmini ifade etmelerine örnek teşkil eden ağızdan ağıza iletişim, tavsiye etme ve tekrar ziyaret etme istekliliği davranışsal niyetlerin olumlu boyutlarını, ürünü ya da işletmeleri şikayet etme, işletmeyi ya da ürünü değiştirme istekliliği ise davranışsal niyetlerin olumsuz boyutlarını ifade etmektedir (Zeithalm vd., 1996).

Literatür incelendiğinde müşteri memnuniyeti ile davranışsal niyetlerin ilişkili olduğuna dair (Kozak, 2001; Yüksel, 2001; Yoon ve Uysal, 2005; Zabkar vd., 2010; Heung ve Gu, 2012; İlban vd., 2015) birçok çalışma bulunmaktadır. Müşteri memnuniyeti ve davranışsal niyetler kavramlarının birbirleri ile olan ilişkisine dair birçok çalışma bulunmasına rağmen bu araştırmalara ilave edilebilecek yöresel yiyecekler ile ilişkin çok fazla çalışmaya rastlanılmamaktadır. Dolayısıyla bu iki kavrama eklenebilecek yöresel yiyecekler ile ilgili yapılan bu çalışma, literatürde yer alan eksikliğin giderilmesi adına önem arz etmektedir.

\section{İlgili Araştırmalar ve Hipotezler}

Wakefield ve Blodgett (1996) yaptıkları çalışmada üç farklı eğlence mekânında gelen müşterilerin memnuniyet düzeylerinin, davranışsal niyetleri üzerine etkileri ölçülmüştür. Bu mekânlarda aldığı hizmet ve ürünlerin kalitesinden memnun olan müşterilerin işletmeye olan davranışsal niyetleri de olumlu ölçüde etkilenmiştir. Sonuç olarak, müşterilerde hizmet ve ürünlerin verildiği işletmede daha fazla zaman geçirme isteği, yeniden satın alma eğilimi ve bu ürün ve hizmetlere daha fazla ücret ödemeye gönüllü yatkınlıklar gözlemlenmiştir.

Hong Kong'da işletilen bir yiyecek içecek işletmesinde, misafirlerin memnuniyetlerinin, tüketim sonrası davranışları üzerinde etkili olduğu tespit edilen bir başka çalışmada Heung ve $\mathrm{Gu}$ tarafından 2012 yılında gerçekleştirilmiştir. Zabkar, Brenčič ve Dmitrović'in (2010) Slovenya'da 1056 katılımcı ile dört değişik destinasyonda gerçekleştirdikleri çalışmada da müşteri memnuniyetinin davranışsal niyetler üzerindeki etkisi yinelenmiştir. Yukarıdaki çalışmalardan ve literatürde yer alan ilgili (Kozak ve Rimmington, 2000; Bigne vd., 2001; Kozak, 2001; Petrick vd., 2001; Yüksel, 2001; Feng ve Jang, 2004; Yoon ve Uysal 2005; Duman ve Öztürk, 2005; Zabkar vd., 2010; Heung ve Gu, 2012; Shi vd., 2014; İlban vd., 2015; İlban vd., 2016) çalışmalardan hareketle, turizm endüstrisinde memnuniyetin davranışsal niyetler üzerinde etkili olduğu düşünülmüştür. 
Bununla birlikte, literatürde yöresel yiyeceklerin turist memnuniyeti ve davranışsal niyetleri üzerine yapılan doğrudan veya dolaylı çalışmalar, ise oldukça sınırlıdır. Ulaşılabilen çalışmalardan biri olan Chi ve arkadaşlarının 2013 yılında gerçekleştirdiği araştırmalarında Malezya'yı ziyaret eden yabancı turistlerin görüşleri ile Malezya'nın yöresel yiyecek imajını belirlenmeye çalışılmıştır. Bu çalışmanın sonucunda, destinasyonu ziyaret eden ve ilgili destinasyon kültürüne yabancı bir ülkeden gelen turistlerin o yörenin yöresel yiyeceklerine karşı beklentilerinin karşılandığı ve bunun sonucunda ise ziyaretlerine ilişkin algıladıkları memnuniyet düzeylerinin arttığı belirtilebilir. Konu üzerine yapılan bir başka çalışmada ise Kim, Eves ve Scarles (2009), bir destinasyonun kendine özgü yiyecek ve içeceklerinin tüketimini etkileyen unsurları belirlemeye çalışmışlardır. Kavramsal bir model etrafında geliştirilen bu çalışmada, turistlerin seyahatleri boyunca gittikleri yörenin yiyecek ve içeceklerini tüketmelerinin üç önemli değişkenin birleşiminden oluştuğu sonucunu ortaya koymuşlardır. $\mathrm{Bu}$ değişkenler; turisti yöresel yiyecek ve içecekleri tüketmeye güdüleyen motivasyon kaynağı, demografik özellikler ile turistin davranış ve tutumlarıdır.

Kivela ve Crotts (2006)'un çalışmalarında turistlerin seyahat ettikleri destinasyon ile ilgili yerel yiyecekler ve gastronomik beklentilerinin turistik deneyimleri üzerindeki etkileri incelenmiştir. Çalışma sonuçlarında gastronomik deneyimlerden kaynaklı memnuniyet hissinin seyahat etmek için önemli bir motivasyon kaynağı olduğu ortaya çıkmıştır. Çalışmada da müşteri memnuniyetinin davranışsal niyetler üzerindeki etkisi yinelenmiştir. Yukarıdaki çalışmalardan ve literatürde yer alan ilgili çalışmalardan hareketle, (Rimmington ve Yüksel, 1998; Nield vd., 2000; Ryu ve Jong, 2006; Kivela ve Crotts, 2006; Kivela ve Crotts, 2009; Kim vd., 2009; Ling vd., 2010; Karim ve Chi, 2010; Lertputtarak, 2012; Chi vd., 2013) turizm endüstrisinde yöresel yiyeceklerin doğru satış ve tutundurma teknikleri ile turistlerin seyahat deneyimlerine olumlu katkıda bulunduğu düşünülmüştür. İlgili Literatürden hareketle turistlerin yöresel yiyecek beğenilerinin memnuniyeti, memnuniyetinde davranışsal niyetleri olumlu etkilediği varsayılmış ve aşağıdaki hipotezler geliştirilmiştir:

H1: Turistlerin yöresel yiyecek beğenilerinin, müşteri memnuniyeti üzerinde anlamlı ve olumlu bir etkisi vardır.

H1a: Turistlerin yöresel ot beğenilerinin, müşteri memnuniyeti üzerinde anlamlı ve olumlu bir etkisi vardır.

H1b: Turistlerin deniz ürünleri beğenilerinin, müşteri memnuniyeti üzerinde anlamlı ve olumlu bir etkisi vardır.

H1c: Turistlerin meze beğenilerinin, müşteri memnuniyeti üzerinde anlamlı ve olumlu bir etkisi vardır.

H1d: Turistlerin salata beğenilerinin, müşteri memnuniyeti üzerinde anlamlı ve olumlu bir etkisi vardır.

H2: Müşteri memnuniyetinin, davranışsal niyet üzerinde anlamlı ve olumlu bir etkisi vardır.

\section{YÖNTEM}

\section{Örneklem ve Veri Toplama}

$\mathrm{Bu}$ araştırmada kullanılan tüm analizler, Balıkesir ili Ayvalık ilçesine bağlı Cunda Adası'nı ziyaret eden yerli turistlerin, etki altında kalmadan kendi düşünceleri ile doğru olarak doldurduğu varsayılan veriler ile gerçekleştirilmiştir. Araştırma kapsamında oluşturulan anket formlarının, katılımcılara ulaştırılması ve katılımcılar tarafından geri dönüşünün sağlanması Temmuz-Ağustos 2016 tarihlerinde gerçekleştirilmiştir. 430 katılımcıya ulaştırılan anket formlarından elde edilen verilerle gerçekleştirilen uç değer analizleri sonucunda, araştırma 
sonuçlarına olumsuz anlamda etki edebileceği tespit edilen 24 anket formu analiz kapsamından çıkartılmış, yapılan analizler 406 katılımcının verileri ile gerçekleştirilmiştir. Anket formu iki ayrı kısımdan oluşmaktadır. Birinci kısım; katılımcıların demografik bulguları ve yiyecek içecek işletmeleri alışkanlıklarını ifade eden bilgilerden oluşmaktadır. Anket formunun ikinci kısmında ise araştırmanın bağımsız değişkenlerini oluşturan ve dört alt boyut ile ölçümlenen 22 ifadeli yöresel yiyecekler ölçeğinden meydana gelmiştir. Bununla birlikte araştırmada bağımlı değişken rolü üstlenen üç ifade ile ölçülen memnuniyet ile araştırmanın sonuç değişkenlerini oluşturan ve yine üç ifade ölçülen davranışsal niyet ölçeği de anketin ikinci kısmında yer almaktadır.

Tablo 1. Araştırmada Kullanılan Ölçekler ve İfadeleri

\begin{tabular}{|c|c|}
\hline Yöresel Otlar & Ölçeğin Edinildiği Çalışma \\
\hline Akkız (Şevket-i Bostan) & \multirow{25}{*}{$\begin{array}{l}\text { Yerli Turist ve Cunda'da } \\
\text { faaliyet gösteren işletme sahip } \\
\text { ve yöneticileri ile yüz yüze } \\
\text { görüşülerek gerçekleştirilen Ön } \\
\text { test sonucunda elde edilmiştir. }\end{array}$} \\
\hline Hindiba & \\
\hline $\begin{array}{l}\text { İstifno } \\
\end{array}$ & \\
\hline Turp Otu & \\
\hline Hardal Otu & \\
\hline Deniz Ürünleri & \\
\hline Levrek & \\
\hline Çupra & \\
\hline Barbun & \\
\hline Mercan & \\
\hline Papalina & \\
\hline Tekir & \\
\hline Kalamar & \\
\hline Ahtapot & \\
\hline Karides & \\
\hline Yöresel Mezeler & \\
\hline Acılı Ezme & \\
\hline Haydari & \\
\hline Fava & \\
\hline Börülce & \\
\hline Patlıcan Közleme & \\
\hline \multirow[b]{2}{*}{ Mevsim Salata } & \\
\hline & \\
\hline Yeşil Salata & \\
\hline Çoban Salata & \\
\hline \multirow{2}{*}{$\begin{array}{l}\text { Müşteri Memnuniyeti } \\
\text { Cunda'daki Restoranlarda Yediğim Yemeklerden Çok } \\
\text { Mutlu Oldum }\end{array}$} & Ölçeğin Edinildiği Çalışma \\
\hline & \\
\hline $\begin{array}{l}\text { Cunda'daki Restoranlarda } \\
\text { Oldukça Memnunum. }\end{array}$ & Yoon vd. (2010) \\
\hline \multicolumn{2}{|l|}{$\begin{array}{l}\text { Genel Olarak Cunda'daki Yemeklerden Memnuniyet } \\
\text { Duydum. }\end{array}$} \\
\hline Davranışsal Niyetler & Ölçeğin Edinildiği Çalışma \\
\hline Cunda'ya Tekrar Gelip Yemek Yemek İsterim. & \multirow{3}{*}{ İlban vd. (2015) } \\
\hline Arkadaşlarıma Cunda'yı Tavsiye Ederim. & \\
\hline $\begin{array}{l}\text { Eşimi, Dostumu Cunda'ya Getirip Yemek Yedirmek } \\
\text { İsterim. }\end{array}$ & \\
\hline
\end{tabular}


Araştırmada kullanılan ölçekler Tablo 1'de gösterilmektedir. Araştırma kapsamında veri tabanı oluşturulabilmesi adına edinilen veriler elektronik ortama aktarılmış ve aktarılan veriler SPSS ve AMOS programları ile analizlere tabi tutulmuştur. Araştırma modelinde kullanılan ölçeklerden yöresel yiyecekler ölçeği; Cunda Adası'nda yer alan restoranlarda kullanılan ürünlerin isimlerinin, kullanım sıklıklarının ve hangi gruplarda menülerde yer aldığının belirlenmesi amacıyla 50 katılımcı ile kapalı görüşme tekniği ile gerçekleştirilen röportaj uygulamasından elde edilmiştir. Belirlenen gruplar anket formunda da ayrı ayrı yer almaktadır. Yine 50 katılımc ile gerçekleştirilen pilot uygulama ile de son hali verilmiş ve 22 ifade ile dört alt boyuttan oluşmaktadır. Modelde yer alan müşteri memnuniyeti ölçeği Yoon ve arkadaşlarının (2010) gerçekleştirdiği çalışmadan alınmış ve üç ifadeden oluşmaktadır. Davranışsal niyetler ölçeği ise İlban ve arkadaşlarının (2015) gerçekleştirdiği çalışmadan alınmış ve bu ölçekte üç ifadeden oluşmaktadır. Araştırma modeline göre yöresel yiyecekler boyutlarının her birinin, memnuniyet ölçeği üzerindeki ayrı ve doğrudan etkileri incelenmiştir. Bununla birlikte memnuniyet ölçeğinin davranışsal niyet üzerinde beklenilen etkileri de modelde yer almıştır.

\section{Verilerin Analizi}

Araştırma kapsamında veri tabanı oluşturulabilmesi adına edinilen veriler elektronik ortama aktarılmış ve aktarılan veriler SPSS ve AMOS programları ile analizlere tabi tutulmuştur. Araştırmada kapsamında ifade edilen demografik bulguların ortaya çıkartılması adına yüzde ve frekans analizlerinden, araştırmada kullanılan ölçeklerin güvenilirlik kat sayılarının incelenmesi açısından Cronbach alpha değerlerinden, araştırmada kullanılan ölçeklerin ayrışma analizlerinin yapılabilmesi bakımından açıklayıcı ve doğrulayıcı faktör analizlerinden ve araştırmada kullanılan ifadelerin araştırma veri tabanında normal dağılım gösterip göstermediğini belirlemek amacıyla Skewness ve Kurtosis değerlerinden yararlanılmıştır. Araştırma modelinde yer alan değişkenler arası etki düzeylerinin belirlenmesi amacı ile de yapısal eşitlik modeli analizi uygulanmıştır.

\section{BULGULAR}

\section{Açıklayıcı Faktör Analizi Sonuçları}

Normallik varsayımının veri tabanında sağlanmasından sonra (Yöresel otlar, Ç: -0,361, B: -0,733, Deniz Ürünleri, Ç: -0,512, B: 0,142, Yöresel Mezeler, Ç: -0,124, B: -0,961 ve Salatalar: Ç: -0,301, B:

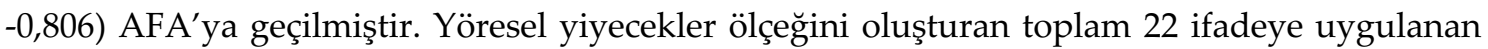
açıklayıcı faktör analizi sonuçlarına göre KMO; 0,895 ve Barlett testinin p değeri ise 0,001 olarak elde edilmiştir. Analizin sonucunda yöresel yiyecekler ölçeğinin açıkladığı toplam varyans $\% 58,985$ olarak bulgulanmıştır. Ölçeklerde bulunan önermelerin en düşük faktör yükü 0,508 en yüksek 0,846 olarak bulgulanmıştır. Açıklanan toplam varyansı açıklama güçlerine göre boyutlar; yöresel otlar boyutu \%17,201, deniz ürünleri \%16,660, mezeler boyutu \%13,105 ve salatalar boyutu \%12,021 olarak sıralanmaktadır. Bağımlı değişkenleri altı önerme (memnuniyet:3, davranışsal niyet:3) ile ifade eden verilere istinaden yapılan AFA sonucunda; $\mathrm{KMO} ; 0,752$ ve Barlett testinin p değeri ise 0,001 olarak elde edilmiştir. İki ölçeği ifade eden önermelerin faktör yükleri 0,730 ve 0,905 arasında değişmektedir. Analizin sonucunda ölçeklerin açıkladığı toplam varyans \%73,511 olarak bulgulanmıştır. Açıklanan toplam varyansı, açıklama güçlerine göre; davranışsal niyetler \%41,406 ve müşteri memnuniyeti $\% 32,105$ olarak siralanmaktadır. 


\section{Doğrulayıcı Faktör Analizi Sonuçları}

Araştırma verilerine uygulanan AFA sonucunda elde edilen yöresel yiyecekler, müşteri memnuniyeti ve davranışsal niyetler isimli üç ölçek ve 25 önerme AMOS programı ile DFA'ya tabi tutulmuştur. Tüm modele yönelik DFA çıtılları Şekil 1'de gösterilmiştir.

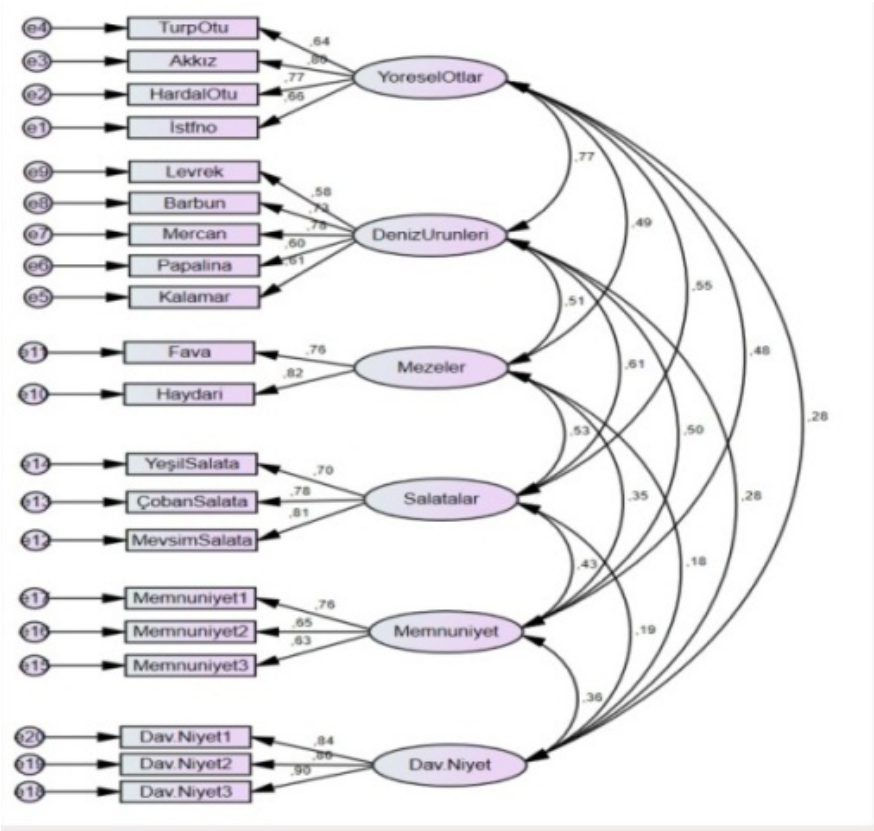

Şekil 1. Tüm Modelin DFA Çıktıları

Tüm model üzerine yapılan DFA sonucunda, hiçbir ifade modelden çıartılmayarak DFA tamamlanmıştır. Şekil 1'de gösterilen parametre değerleri incelendiğinde, en düşük değerin 0,58 , en yükseğin ise 0,90 olduğu görülmektedir. Bu sonuçlar standardize edilmiş kat sayıların ideal değerlerde olduğunu göstermektedir. Tüm model üzerine uygulanan DFA'nın, uyum iyiliği değerleri incelemeye alınmış ve bu çıktılar Tablo 2' de gösterilmektedir.

Tablo 2. Tüm Modele Uvgulanan DFA Sonucunda Elde Edilen Uvum İviliği Değerleri

Uyum

Ölçütleri Mükemmel Uyum Kabul Edilebilir Uyum

Ölçeğin Uyum

\begin{tabular}{l|ccc}
\hline $\mathrm{c}^{2} / \mathrm{df}$ & $0 \leq \mathrm{c} 2 / \mathrm{df} \leq 2$ & $2 \leq \mathrm{c} 2 / \mathrm{df} \leq 3$ & 2,080 \\
RMSEA & $0 \leq \mathrm{RMSEA} \leq 0,05$ & $0,05 \leq \mathrm{RMSEA} \leq 0,08$ & 0,052 \\
RMR & $0 \leq \mathrm{SRMR}<0,05$ & $0,05 \leq \mathrm{SRMR}<0,10$ & 0,044 \\
NFI & $0,95 \leq \mathrm{NFI} \leq 1$ & $0,90 \leq \mathrm{NFI}<0,95$ & 0,909 \\
CFI & $0,97 \leq \mathrm{CFI} \leq 1$ & $0,95 \leq \mathrm{CFI}<0,97$ & 0,950 \\
GFI & $0,95 \leq \mathrm{GFI} \leq 1$ & $0,80 \leq \mathrm{GFI}<0,95$ & 0,927 \\
AGFI & $0,90 \leq \mathrm{AGFI} \leq 1$ & $0,85 \leq \mathrm{AGFI} \leq 0,90$ & 0,902 \\
\hline
\end{tabular}

Kaynak: Scherbelleh-Engel ve Moosbrugger (2003), Çokluk, Şekercioğlu ve Büyüköztürk (2012), Meydan ve Şeşen (2011).

Tablo 2'de DFA sonucunda elde edilen uyum iyiliği değerleri incelendiğinde; SRMR ve AGFI değerlerinin mükemmel uyum, geriye kalan bütün uyum iyiliği değerlerinin ise kabul edilebilir (c²/df, CFI, NFI, RMSEA, GFI) uyum iyiliği değerleri gösterdikleri anlaşılmaktadır. Buradan hareketle DFA sonucunda verilerin iyi bir uyuma sahip olduğu anlaşılmaktadır.

Tüm modele dair gerçekleştirilen DFA sonucunda hem yakınsak hem de ıraksak açıdan geçerliliğinin olduğunu anlayabilmek için modelin geçerlilik, güvenilirlik ve korelasyon katsayıları incelenmiştir. Ölçeğin yakınsak geçerliliğinin anlaşılabilmesi adına AVE değerinin 
0,50'nin üzerinde, CR değerinin ise 0,70 üzerinde olması ve CR değerinin AVE değerinden yüksek olması gerekmektedir (Hair vd., 2014). Ölçeklerin yakınsak geçerliliğinin sağlanabilmesi için korelasyon matrisini oluşturan korelasyon katsayılarının 0,85'den küçük olması gerekmektedir (Kline 2005; Akt: Akbıyık ve Coşkun, 2013). Bu bilgiler ışığında ortaya çıkan sonuçlar Tablo 3'te gösterildiği gibidir.

Tablo 3. Tüm Modele Uygulanan DFA sonuçlarına dair CR, AVE ve Korelasyon Katsayıları

\begin{tabular}{|c|c|c|c|c|c|c|c|c|}
\hline & $\mathrm{CR}$ & AVE & 1 & 2 & 3 & 4 & 5 & 6 \\
\hline Memnuniyet (1) & 0,720 & 0,503 & (1) & & & & & \\
\hline Yöresel Otlar (2) & 0,706 & 0,524 & $0,477^{*}$ & (1) & & & & \\
\hline Deniz Ürünleri (3) & 0,795 & 0,510 & $0,497^{*}$ & $0,733^{*}$ & (1) & & & \\
\hline Salatalar (4) & 0,772 & 0,629 & $0,346^{*}$ & $0,552^{*}$ & $0,510^{*}$ & (1) & & \\
\hline Mezeler (5) & 0,808 & 0,585 & $0,430^{*}$ & $0,491^{*}$ & $0,609^{*}$ & $0,532^{*}$ & (1) & \\
\hline Dav. Niyet (6) & 0,899 & 0,748 & $0,361^{*}$ & $0,285^{*}$ & $0,284^{*}$ & $0,183^{*}$ & $0,190^{*}$ & (1) \\
\hline
\end{tabular}

${ }^{*}$ Korelasyon anlamlılık katsayısı

Tablo 3'te araştırma modelinde yer alan tüm değişkenlerin $C R$ değerinin 0,70 'in üstünde olduğu görülmektedir. Tablo 2'de modelde yer alan tüm değişkenlere ait AVE değerlerinin 0,50'den yüksek ve CR değerlerinin de AVE değerlerinden yüksek olduğu gözlemlenmiştir. Tablo 3 incelendiğinde korelasyonların en yükseğinin 0,609 ile deniz ürünleri ve mezeler boyutları arasında olduğu ve saptanan bu değerin $0,85^{\prime}$ den küçük olduğu görülmektedir.

\section{Ölçeklerin Normal Dağılım Sonuçları}

Parametrik hipotez testlerinin uygulanabilmesi için sağlanması gereken en önemli koşullardan birisi verilerin normal dağılım gösterip göstermediğidir. Normallik varsayımının gerçekleşebilmesi için basıklık ve çarpıklık değerlerinin $+1,50$ ve $-1,50$ değerleri arasında olması gerekmektedir (Tabachnick ve Fidel 2013). Yöresel yiyecekler ölçeğinin alt boyutlarının basıklık ve çarpıklık değerleri (Yöresel otlar, Ç: -0,361, B: -0,733, Deniz Ürünleri, Ç: -0,512, B: 0,142, Yöresel Mezeler, Ç: -0,124, B: -0,961 ve Salatalar: Ç: -0,301, B: -0,806) bu koşulu sağlamaktadır. Bununla birlikte araştırmada kullanılan diğer ölçeklerden müşteri memnuniyeti ve davranışsal niyetler ölçeklerinin basıklık ve çarpıklık değerleri (Müşteri Memnuniyeti, Ç: -0,407, B: 0,511, Davranışsal Niyetler, Ç: $-0,439$, B: -0,668) kullanılan ölçeklerin normal dağılıma sahip olduklarını göstermektedir.

\section{Ölçeklerin Güvenilirlik Katsayıları}

Araştırma modelinde yer alan üç ölçek ve bu ölçeklere bağlı dört alt boyut için cronbach alpha katsayıları ayrı ayrı analiz edilmiştir. Analiz sonucunda her bir ifadenin kendi ait olduğu boyutun güvenilirliğine herhangi bir olumsuz katkısının olmaması ve bununla birlikte alpha değerlerinin 0,714 ve 0,899 arasında olması (Hair vd., 1995) araştırma sonuçları için beklenen bulguları doğrular niteliktedir. Bu sonuçların dışında ölçek üzerine uygulanan genel güvenilirlik kat sayısının (Cronbach's Alpha $=0,902$ ) yüksek olması, ölçeğin kendi içerisinde tutarlı olduğunu göstermektedir. Araştırmada kullanılan değişkenlerin güvenilirlikleri Yöresel Otlar; 0,811, Deniz Ürünleri;0,807, Mezeler; 0,780, Salatalar; 0,805, Memnuniyet; 0,714 ve Davranışsal Niyetler; 0,899 şeklindedir. 


\section{Hipotezlerin Testi}

Araştırma amacında belirlenen etkilerin test edilebilmesi amacıyla yapısal eşitlik modellemesinden (YEM) yararlanılmıştır. Araştırma modeli içerisinde karmaşık ilişkileri test edebilmek için, öncelikle araştırma modeli verilerinin anlamlı ve geçerli olup olmadığ değerlendirilmek için uyum iyiliği değerlerinden yararlanılmıştır. YEM analizinin uyum iyiliği değerleri Tablo 4'de sunulmuştur.

Tablo 4. Tüm Modele İlişkin Elde Edilen Uyum İyiliği Değerleri

\begin{tabular}{cccc}
\hline $\begin{array}{c}\text { Uyum } \\
\text { Ölçütleri }\end{array}$ & Mükemmel Uyum & Kabul Edilebilir Uyum & $\begin{array}{c}\text { Modelin Uyum } \\
\text { Değerleri }\end{array}$ \\
\hline c2/df & $0 \leq \mathrm{c} 2 / \mathrm{df} \leq 2$ & $2 \leq \mathrm{c} 2 / \mathrm{df} \leq 3$ & 2,064 \\
RMSEA & $0 \leq \mathrm{RMSEA} \leq 0,05$ & $0,05 \leq \mathrm{RMSEA} \leq 0,08$ & 0,051 \\
RMR & $0 \leq \mathrm{SRMR}<0,05$ & $0,05 \leq \mathrm{SRMR}<0,10$ & 0,047 \\
NFI & $0,95 \leq \mathrm{NFI} \leq 1$ & $0,90 \leq \mathrm{NFI}<0,95$ & 0,908 \\
CFI & $0,97 \leq \mathrm{CFI} \leq 1$ & $0,95 \leq \mathrm{CFI}<0,97$ & 0,950 \\
GFI & $0,95 \leq \mathrm{GFI} \leq 1$ & $0,80 \leq \mathrm{GFI}<0,95$ & 0,926 \\
AGFI & $0,90 \leq \mathrm{AGFI} \leq 1$ & $0,85 \leq \mathrm{AGFI} \leq 0,90$ & 0,902 \\
\hline
\end{tabular}

Kaynak: Scherbelleh-Engel ve Moosbrugger (2003), Çokluk, Şekercioğlu ve Büyüköztürk (2012), Meydan ve Şeşen (2011).

Tablo 4'de YEM sonucunda elde edilen uyum iyiliği değerleri incelendiğinde; SRMR ve AGFI değerlerinin mükemmel uyum, geriye kalan bütün uyum iyiliği değerlerinin ise kabul edile bilir uyum iyiliği değerleri gösterdikleri anlaşılmaktadır. Buradan hareketle YEM sonucunda verilerin iyi bir uyuma sahip olduğu anlaşılmaktadır. YEM'e bağlı olarak yol analizi sonuçları Tablo 5'de gösterilmektedir.

Tablo 5. Hipotez Sonuçları

\begin{tabular}{llllll}
\hline Hipotez & Yapısal İlişki & $\begin{array}{l}\text { Std. Regresyon } \\
\text { Kaysayısı }(\beta)\end{array}$ & Std. Hata & Anlamlılık & $\begin{array}{l}\text { Hipotez } \\
\text { Kabul/Red }\end{array}$ \\
\hline H1a & Mem.<--- Yör.Ot. & 0,194 &, 071 & $0,044^{*}$ & KABUL \\
H1b & Mem.<--- Den.Ür. & 0,244 &, 156 & $0,047^{*}$ & KABUL \\
H1c & Mem.<--- Mezeler & 0,052 &, 074 & 0,505 & RED \\
H1d & Mem.<--- Salatalar & 0,153 &, 080 & 0,073 & RED \\
H2 & Dav. <--- Mem. & 0,386 &, 065 & $0,001^{*}$ & KABUL \\
\hline
\end{tabular}

Anlamlılık: ${ }^{*} \mathrm{P}<0,05,{ }^{* *} \mathrm{P}<0,01$

${ }^{*} \mathrm{H} 1$ hipotezlerine ilişkin sonuçlar: $\mathrm{H} 1$ hipotezi $\mathrm{H} 1_{\mathrm{a}}, \mathrm{H} 1_{\mathrm{b}}, \mathrm{H} 1_{\mathrm{c}}$ ve $\mathrm{H} 1_{\mathrm{d}}$ hipotezleri olarak dört alt hipotez şeklinde değerlendirilmeye alınmıştır. Bunun sonucunda; yöresel yiyeceklerin, yöresel otlar (p:0,04; $\beta: 0,19)$ ve deniz ürünleri (p:0,04; $\beta: 0,24)$ alt boyutlarının, memnuniyet üzerinde pozitif yönlü ve anlamlı bir etkisi bulunmaktadır. Ancak, yöresel yiyeceklerin; mezeler (p:0,50; $\beta: 0,05)$ ve salatalar ( $\mathrm{p}: 0,07 ; \beta: 0,15)$ alt boyutlarının memnuniyet üzerinde pozitif bir etkisi olmasına rağmen anlamlı bir etkisinin olmadığı tespit edilmiştir.

${ }^{*} \mathbf{H} 2$ hipotezlerine ilişkin sonuçlar: Memnuniyet değişkenin (p:0,01; $\left.\beta: 0,38\right)$ davranışsal niyet değişkeni üzerinde anlamlı ve pozitif yönlü bir etkisi bulunmaktadır.

\section{TARTIŞMA, SONUÇ VE ÖNERİLER}

Günümüzde; yöresel yiyeceklere olan ilgi ve talebin hızla artması bölge tanıtımı ve ekonomisinde büyük bir katma değer yapabilecek potansiyel taşımaktadır. Konu ile ilgili 
literatürde yapılan birçok çalışmada, (Rimmington ve Yüksel, 1998; Nield vd., 2000; Ryu ve Jong, 2006; Kivela ve Crotts, 2006; Kivela ve Crotts, 2009; Kim vd., 2009; Ling vd., 2010; Karim ve Chi, 2010; Lertputtarak, 2012; Chi vd., 2013) çalışma sonuçlarına paralel şekilde yöresel yiyeceklerin doğru satış ve tutundurma teknikleri ile turistlerin seyahat deneyimlerine olumlu katkıda bulunduğu belirtilmiştir. Çalışma sonuçlarına göre, turist memnuniyeti üzerinde istatistiki olarak anlamlı ve pozitif etki bırakan iki bağımsız değişkene rastlanmıştır. Bu değişkenler: deniz Ürünleri ve yöresel otlardır. Diğer iki değişken olan Cundanın meze ve salataları ise memnuniyet üzerinde anlamlı bir değişim gösterememişlerdir. Bir tüketici olarak turist, gerek yaşadığ yörede gerekse tatili esnasında meze ve salata gibi kolayda erişilebilecek besinleri rahatlıkla bulup tüketebilir. Bu da bu tür besinlerin turistin gözünde memnuniyet ölçüsü olmamaktadır. Ancak yöreye ait olan ve yöre tarafından iyi pazarlanan yöre menşeili ürünlere karşı turistin tutumları farklılık göstermektedir. Nitekim, bu durum, Cunda'nın deniz ürünlerini ve yöresel otlarını tadan turistlerde kendini göstermiştir. Cunda'nın deniz ürünlerinin göreceli olarak zengin olması bir sahil ve balıkçı kasabası kimliği taşıması ve deniz ürünleri satışı üzerine profesyonelleşmiş yiyecek ve içecek işletmelerinin nicel anlamda yoğunluğu gibi nedenler deniz ürünlerine duyulan beğeninin turist memnuniyeti üzerindeki anlamlı ve olumlu etkisini açıklamaktadır. Sonuç olarak; bu çalışmada turistlerin yöresel yiyecek beğenilerinin, memnuniyetleri üzerindeki etki, literatürde yer alan diğer çalışma sonuçları ile paralel olarak bulgulanmıştır (Ryu ve Jong, 2006; Kivela ve Crotts, 2006; Kim vd., 2009; Ling vd., 2010; Chi vd., 2013).

Çalışmanın ikinci bir amacı olan turist memnuniyetinin turistin davranışsal niyeti üzerine etkileri literatürde ön görüldüğü gibi (Kozak, 2001; Yoon ve Uysal, 2005; Zabkar vd., 2010; Heung ve Gu, 2012; İlban vd., 2015; İlban vd., 2016) sonuçlanmıştır. Araştırma sonucuna göre turist memnuniyetindeki bir birimlik değişim satın alım sonrası gerçekleştireceği davranışsal niyeti üzerinde 0,40 oranında bir etki göstermektedir (B:0,386). Seyahatinden ve seyahati boyunca yaşadığı deneyimlerden haz duyan bir turist bu duygulanımını davranışsal boyutta yöreyi tekrar ziyaret etme isteği, o yöre ürün ve hizmetlerini tekrar satın alma niyeti ve eş dost, akrabalarına tavsiye etme isteği ile dışa vurur. Buradan hareketle, bu çalışma özelinde, Cunda'yı ziyaret eden yerli turistler için Cunda'nın yöresel lezzetlerini tatmak, seyahatleri için birincil motivasyon kaynağı olmayabilir. Ancak bu ürünlerin satın alımından sonra geliştirdikleri davranışlar, memnuniyet düzeyini olumlu etkileyerek, Cunda'ya yapacakları ikinci bir ziyaret için temel motivasyon kaynaklarının başında gelebilmektedir. Böylesi bir durum, ağırlıklı olarak ekonomik ve istihdam kaynağı olan turizm sektörü üzerine inşa edilir bir yer olan Cunda ve Ayvalık'ın geleceği için yüksek bir katma değer yaratabilir.

Balıkesir ili Ayvalık ilçesi; Türkiye iç turizmi değerlendirildiğinde önemli destinasyonlardan biri olarak karşımıza çıkmaktadır. Ancak; iç turizm bağlamında hareket eden turistlerin Ayvalık ya da Cunda Adası özelinde bulunan yöresel tatları bilmemeleri yeme - içme harcamaları noktasında Ayvalık turizm gelirlerinin istenilen seviyeye gelmemesine sebep olmaktadır. Bu duruma alternatif olarak tüm turizm paydaşları, günümüz yerli turistine ve çok daha önemlisi gelecek nesillerin turizm hareketliliği içerisinde bulunabilecek turistlerine, bölgenin yöresel lezzetlerinin tanıtımı ve tecrübe edinimi faaliyetlerini sağlayarak Cunda yöresel tatlarının bilhassa iç turizmde bilinirliğinin arttırılmasında önemli rol oynayabilir. Cunda'nın özellikle deniz ürünleri ve yöresel otları bakımından yoğun çeşitlilik göstermesi ve talep görme potansiyeli taşıması etkili bir pazarlama aracı olarak kullanılabilir. Yörede yapılacak ve konsepti yine yörede yetişen otlar üzerine olacak bir festival veya etkinlik özel ilgi turizmi kapsamında değerlendirilebilir. Araştırmaya konu edilen Cunda Adası yöresel yiyecekleri için gastronomi atölyeleri kurularak, üreticilerin ve yerel halkın, doğru envanterler kullanarak yapabileceği füzyon mutfak uygulamaları ile yeni lezzetlere ulaşılabilir. 
Yapılan bu çalışma özelinde gastronomi turizmi ile ilgili tek, pazarlama literatürü ile ilgili iki temel değişken kullanılmıştır. Gelecekte yapılabilecek araştırmaların içerisinde farklı değişkenlerin kullanımı (Algılanan hizmet kalitesi, ürün ilgilenimi, imaj vb.) ile araştırmalar zenginleştirilebilir. Araştırma Cunda özelinde yapılmıştır ve herhangi bir destinasyonla karşılaştırılması yapılmayarak sınırlandırılmıştır. Gelecekte yapılacak çalışmalarda farklı destinasyonların kullanımı ve kullanılan destinasyonların diğer destinasyonlar ile karşılaştırılması önemli sonuçlar doğurabilir.

\section{KAYNAKÇA}

Akbıyık, A. ve Coşkun, E. (2013). Eğitsel Sosyal Yazılımların Kabul ve Kullanımına Yönelik Bir Model, AJIT-e: Online Academic Journal of Information Technology, 4(13).

$\mathrm{Au}$, N. and Law, R. (2002). Categorical Classification of Tourism Dining, Annals of Tourism Research, 29(3), 819-833.

Baytekin, P. (2005). Toplam Kalite Hedefinde Müşteri Memnuniyetinden Müşteri Sadakatine, Yeni Düşünceler Dergisi, 1(1), 41-52.

Bendall-Lyon, D. and Powers, T. L. (2004). The Impact of Structure and Process Attributes on Satisfaction and Behavioral Intentions, Journal of Services Marketing, 18(2), 114-121.

Bigne, J. E., Sanchez, M. I. and Sanchez, J. (2001). Tourism Image, Evaluation Variables and After Purchase Behaviour: İnter-Relationship. Tourism Management, 22(6), 607-616.

Bozkurt, A., Chao, T. C. and Xu, X. G. (2001). Fluence-To-Dose Conversion Coefficients Based on The VIP-Man Anatomical Model And MCNPX Code For Monoenergetic Neutrons Above 20 Mev, Health Physics, 81(2), 184-202.

Chi, C. G. Q., Chua, B. L., Othman, M., and Karim, S. A. (2013). Investigating the Structural Relationships Between Food Image, Food Satisfaction, Culinary Quality and Behavioral Intentions: The Case of Malaysia. International Journal of Hospitality and Tourism Administration, 14(2), 99-120.

Çokluk, Ö., Şekercioğlu, G. ve Büyüköztürk, Ş. (2012). Sosyal Bilimler İçin Çok Değişkenli İstatistik Spss ve Lisrel Uygulamaları. Ankara: Pegem Akademi Yayınları.

Dalgıç, A., Güler, O. ve Birdir, K. (2016). Tripadvisor.com'da Yer Alan Restoran Şikâyetlerinin Analizi: Mersin ve Hatay'da Yöresel Yiyecek Sunan Restoranlara Yönelik Bir Araştırma, Journal of Tourism and Gastronomy Studies, 4(1), 153-173.

Deveci, B., Türkmen, S. ve Avcıkurt, C. (2013). Kırsal Turizm ile Gastronomi Turizmi İlişkisi: Bigadiç Örneği, Uluslararası Sosyal ve Ekonomik Bilimler Dergisi, (2), 29-34.

Doğdubay, M., Sarıoğlan, M., Saatçi, G. ve Sü Eroz, S. (2011). Destinasyon Pazarlamasında Yerel Yönetimlerin Gastronomik Öğeleri Kullanma Eğilimlerinin Ölçülmesine Yönelik Bir Araştırma, V. Ulusal Gastronomi Sempozyumu.

Gastronomi Turizmi Derneği, (2018), http://www.gastronomiturizmidernegi.com.tr/ Erişim Tarihi: 02.01.2018.

Green, G. P. ve Dougherty, M. L. (2008). Localizing Linkages For Food and Tourism: Culinary Tourism as A Community Development Strategy. Community Development, 39(3), 148-158.

Hair Jr, J. F. and Lukas, B. (2014). Marketing Research (Vol. 2). McGraw-Hill Education Australia. 
Hair Jr, J. F., Anderson, R. E., Tatham, R. L. and William (1995), Multivariate Data Analysis with Readings. New Jersy: Prentice Hall.

Hatipoğlu, A., Zengin, B., Batman, O. ve Şengül, S. (2013). Yöresel Yemeklerin, Kırsal Turizm İşletmeleri Mönülerinde Kullanım Düzeyleri: Gelveri Örneği, Uluslararası Sosyal ve Ekonomik Bilimler Dergisi, 3(1), 6-11.

Heung, V. C and Gu, T. (2012). Influence of Restaurant Atmospherics on Patron Satisfaction and Behavioral Intentions, International Journal of Hospitality Management, 31(4), 1167-1177.

İlban, M. O., Bezirgan M. ve Çolakoğlu, F., (2016). Yöresel Yiyeceklerin Turistlerin Davranışsal Niyetlerine Etkisi: Cunda Adası Örneği, 3rd Internatıonal Congress of Tourısm and Management Researches Proceeding Book. Antalya. 426 - 439.

İlban, M. O., Bezirgan, M. ve Çolakoğlu, F. (2015). Termal Otellerde Algılanan Hizmet Kalitesi, Memnuniyet ve Davranışsal Niyetler Arasındaki İlişkilerin İncelenmesi: Edremit Örneği, Anatolia: Turizm Araştırmaları Dergisi, 27(2), 181-194.

Kim, H. K., Lee, T. J. and Yoon, S. H. (2012). Factors Affecting Consumer's Choice of Ethnic Restaurants, Tourism Analysis, 17(3), 377-383.

Kim, Y. G., Eves, A. and Scarles, C. (2009). Building A Model of Local Food Consumption on Trips and Holidays: A Grounded Theory Approach, International Journal of Hospitality Management, 28(3), 423-431.

Kivela, J. and Crotts, J. C. (2006). Tourism and Gastronomy: Gastronomy's Influence on How Tourists Experience A Destination, Journal of Hospitality and Tourism Research, 30(3), 354-377.

Kozak, M. (2001). Repeaters' Behavior at Two Distinct Destinations, Annals of tourism research, 28(3), 784-807.

Lin, I. Y. H. and Mattila, A. S. (2006). Understanding Restaurant Switching Behavior from A Cultural Perspective, Journal of Hospitality ve Tourism Research, 30(1), 3-15.

Ling, L. Q., Karim, M. S. A., Othman, M., Adzahan, N. M., and Ramachandran, S. (2010). Relationships Between Malaysian Food Image, Tourist Satisfaction and Behavioural Intention, World Applied Sciences Journal, (Tourism and Hospitality), (10).164-171.

Lopez-Guzman, T. and Sanchez-Canizares, S. (2012). Gastronomy, Tourism and Destination Differentiation: A Case Study in Spain, Review of Economics and Finance, 1, 63-72.

Mak, A. H., Lumbers, M., Eves, A., and Chang, R. C. (2012). Factors Influencing Tourist Food Consumption, International Journal of Hospitality Management, 31(3), 928-936.

Meydan, H. C., ve Şeşen, H. (2011). Yapısal Eşitlik Modellemesi AMOS Uygulamaları. Ankara: Detay Yayıncilık.

Oliver, R. L. (1981). Measurement and Evaluation of Satisfaction Processes In Retail Settings, Journal of retailing.

Parasuraman, A., Berry, L. L. and Zeithaml, V. A. (1991). Refinement and Reassessment of The SERVQUAL Scale, Journal of retailing, 67(4), 420.

Scherbelleh-Engel, K., ve Moosbrugger, H. (2003). Evaluating the Fit of Structural Equation Models: Tests of Significance and Descriptive Goodness-of-it Measures. Methods of Psychological Research Online, 2(8), 23-74.

Tabachnick and Fidell, (2013). B.G. Tabachnick, L.S. Fidell Using Multivariate Statistics (sixth ed.) Pearson, Boston. 
TÜIK, (2018). https://biruni.tuik.gov.tr/medas/?kn=74andlocale=tr Erişim Tarihi: 02.01.2018.

Wakefield, K. L. and Blodgett, J. G. (1996). The Effect of The Servicescape on Customers' Behavioral Intentions in Leisure Service Settings, Journal of services marketing, 10(6), 45-61.

Warde, A. (1997). Consumption, Food and Taste. Sage.

Yang, J., Gu, Y. and Cen, J. (2011, February). Festival Tourists' Emotion, Perceived Value, and Behavioral İntentions: A Test of The Moderating Effect of Festivalscape, In Journal of Convention and Event Tourism (Vol. 12, No. 1, pp. 25-44). Taylor and Francis Group.

Yetiş, Ş. A. (2015). Kapadokya Yemek Kültürü ve Mustafapaşa Beldesi (Sinasos) Örneği Regional Cuisine, Journal of Tourism and Gastronomy Studies, 12, 19.

Yoon, Y. and Uysal, M. (2005). An Examination of The Effects of Motivation and Satisfaction on Destination Loyalty: A Structural Model, Tourism management, 26(1), 45-56.

Yoon, Y. S., Lee, J. S. and Lee, C. K. (2010). Measuring Festival Quality and Value Affecting Visitors' Satisfaction and Loyalty Using A Structural Approach, International Journal of Hospitality Management, 29(2), 335-342.

Žabkar, V., Brenčič, M. M. and Dmitrović, T. (2010). Modelling Perceived Quality, Visitor Satisfaction and Behavioural Intentions At the Destination Level, Tourism management, 31(4), 537-546.

Zeithaml, V. A. (2000). Service Quality, Profitability, and The Economic Worth of Customers: What We Know and What We Need to Learn, Journal of The Academy of Marketing Science, 28(1), 67-85.

Zeithaml, V. A., Berry, L. L. and Parasuraman, A. (1996). The Behavioral Consequences of Service Quality, The Journal of Marketing, 31-46. 